\title{
Exhaled Bioaerosols from Asymptomatic COVID-19 carriers- A Potential Risk in Orthodontics?
}

\author{
Saravana Karthikeyan Balasubramanian ${ }^{1, *\left({ }^{\circ}\right.}$, Divya VC ${ }^{2}$
}

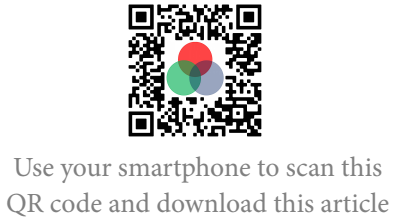

${ }^{1}$ Conservative Dentistry and Endodontics, SRM Dental College, Ramapuram, SRM Institute of Science and Technology, Chennai- 600089 , Tamil Nadu, India

${ }^{2}$ Oral Medicine and Radiology, SRM Kattankulathur Dental College and Hospitals, SRM Institute of Science and Technology, Chennai- 603 203, Tamil Nadu, India

\section{Correspondence}

Saravana Karthikeyan Balasubramanian, Conservative Dentistry and Endodontics, SRM Dental College, Ramapuram, SRM Institute of Science and Technology, Chennai- 600 089, Tamil Nadu, India

Email: saravanb@srmist.edu.in

\section{History}

- Received: Sep 11, 2021

- Accepted: Oct 27, 2021

- Published: Nov 29, 2021

DOI : 10.15419/bmrat.v8i11.703

\section{Check for updates}

\section{Copyright}

(- Biomedpress. This is an openaccess article distributed under the terms of the Creative Commons Attribution 4.0 International license.

\begin{abstract}
The current manuscript sheds light on the possible role of bioaerosols (from mouth breathing) that may serve as vectors for transmitting COVID-19 in asymptomatic carriers reporting to dental hospitals and, hence, may pose a great challenge for even a simple orthodontic diagnosis. Further, we would like to add a few preventive considerations for containment of this novel disease spread via bioaerosols emitted, particularly during mouth breathing.

Key words: Bioaerosols, Coronavirus, Disease spread, Mouth breathing, Orthodontics, Pandemic
\end{abstract}

\section{INTRODUCTION}

Coronavirus disease (COVID-19) has posed great challenges presently and, in that, the role of healthcare professionals in preventing the spread of transmission is extremely significant. The novel disease has spread rapidly to several countries, affecting 223,022,538 people worldwide, causing 4,602,882 deaths on September 10, 2021, according to the reports of the WHO (World Health Organization, 2020) ${ }^{1}$. In view of this global pandemic that is quite alarming, WHO has stressed the importance of basic protective measures, mainly being hand hygiene and social distancing ${ }^{2}$.

\section{PRE-SYMPTOMATIC TRANSMISSION OF COVID 19}

Recently, researchers reported that the novel coronavirus disease 2019 (COVID-19) spreads from asymptomatic carriers. The latest evidence suggests that pre-symptomatic transmission by viral shedding is quite possible, occurring just 2-3 days before the symptoms' onset ${ }^{3,4}$. Interestingly, the infectious profile of SARS-CoV-2 resembles more likely that of influenza rather than SARS ${ }^{4}$. At this stage, the exact mechanism by which the asymptomatic individuals acquire and spread the virus at the pre-symptomatic period is under exploratory research. We would like to emphasize our notable observations.

\section{PRE-SYMPTOMATIC TRANSMISSION OF COVID 19}

Literature evidence suggests that any infectious material in a true aerosol form (i.e., $<50 \mu m$ diameter) becomes re-airborne as droplet nuclei that linger in the atmosphere for up to 30 minutes, thereby expanding the spatial extent of emitted particles ${ }^{5,6}$. Apart from speaking/coughing, aerosols are also generated during normal breathing, commonly referred to as "exhaled bioaerosols" consisting of airway-lining fluid in small droplets ${ }^{7}$. Mouth breathing is another significant overlooked factor, producing the largest number of airborne droplets $(<1 \mu \mathrm{m})$ much more than breathing, speaking, and coughing, definitely posing a threat ${ }^{8}$. These emitted particles act as vectors for the spread of various infectious diseases, including influenza in the past and hence, we have to consider the impact of these bioaerosols on the current pandemic too. This could be one of the probable reasons that COVID-19 is highly transmissible between the subjects in the pre-symptomatic and/or asymptomatic stage ${ }^{3,4}$.

\section{EXHALED BIOAEROSOLS- A RISK FACTOR IN ORTHODONTIC PATIENTS?}

More recently, it has been reported that bioaerosols from mouth breathing serve as an under-recognized transmissible mode in SARS-CoV-2 infection ${ }^{9}$. This builds up internal pressure since we are at high exposure risk as health care professionals. The probability of risk transmission is quite high, especially in the case of mouth-breathing individuals who report with one or more significant orthodontic findings seeking treatment. Hence, the disease control measures for COVID-19 should be adjusted to account for probable substantial pre-symptomatic transmission, as stated earlier ${ }^{4}$. However, we would like to add considerations for containment of the spread 
via bioaerosols emitted, particularly during mouth breathing or normal breathing. More recently, Anfinrud et al. (2020) visualized speech-generated salivary droplets with and without masks by laser light scattering and qualitatively reported the significance of a damp cloth cover over the oral cavity to curb droplets emission ${ }^{10}$.

\section{SUGGESTED PREVENTIVE MEASURES}

It was also reported in an earlier study by Edward et al. ${ }^{7}$ that nebulized suspension containing isotonic saline and surfactants like 1,2-Dipalmitoylsn-glycero-3-phosphocholine (DPPC) and 1-94 palmitoyl-2-oleoyl-sn-glycero-3-phosphoglycerol (POPG) significantly reduced the exhaled aerosols by altering the physical properties of the lung-lining fluid, notably, surface tension and viscosity in "super spreaders" (i.e., high bioaerosol producers). Hence, this prophylactic inhalation measure can also be considered to combat COVID-19 transmission effectively via asymptomatic carriers, added to other defensive actions including isolation, enhanced personal hygiene, and use of face masks/shields as proposed. Further, filtering facepiece masks (FFP), especially FFP3 that possess a high filtration rate (99\%), can be highly recommended amongst dentists to contain the airborne spread of the virus ${ }^{11,12}$.

\section{CONCLUSION}

Therefore, it is understood that the generation of bioaerosols is an inevitable and never-ending process. Bioaerosols are omnipresent, and the exhaled bioparticles from asymptomatic COVID-19 carriers are a potential threat. The risk of transmission increases multifold, particularly in individuals with compromised immune systems due to debilitating diseases. Since there are no definite therapies available for the treatment of COVID-19 presently, it is indispensable to adopt the aforesaid prophylactic preventive actions carefully.

\section{ACKNOWLEDGMENTS}

None.

\section{AUTHOR'S CONTRIBUTIONS}

Conceptualization: B. Saravanakarthikeyan and Divya VC

Writing- Original Draft Preparation: Divya VC

Writing- Review \& Editing: B. Saravanakarthikeyan All authors read and approved the final manuscript.

\section{FUNDING}

None.

\section{AVAILABILITY OF DATA AND MATERIALS}

Not applicable.

\section{ETHICS APPROVAL AND CONSENT TO PARTICIPATE}

Not applicable.

\section{CONSENT FOR PUBLICATION}

Not applicable.

\section{COMPETING INTERESTS}

The authors declare that they have no competing interests.

\section{REFERENCES}

1. World Health Organization (WHO), Coronavirus Disease 19 (COVID-19) Situation Reports. https://www.who.int/emergen cies/diseases/novel-coronavirus-2019/situation-reports. Last accessed online on September 112021.

2. World Health Organization (WHO), Coronavirus disease (COVID-19) advice for the public, Last updated March 18 2020, World Health Organization, Genewa, Switzerland, 2020. https://www.who.int/emergencies/diseases/novel-coronavir us-2019/advice-for-public.

3. Bai Y, Yao L, Wei T, Tian F, Jin DY, Chen L. Presumed Asymptomatic Carrier Transmission of COVID-19. Journal of the American Medical Association. 2020;323(14):1406-7. PMID: 32083643. Available from: 10.1001/jama.2020.2565.

4. He X, Lau EH, Wu P, Deng X, Wang J, Hao X. Temporal dynamics in viral shedding and transmissibility of COVID-19. Nature Medicine. 2020;26(5):672-5. PMID: 32296168. Available from: 10.1038/s41591-020-0869-5.

5. Hinds WC. Aerosol technology: Properties, behavior, and measurement of airborne particles. New York (NY): Wiley; 1982.

6. Harrel SK, Molinari J. Aerosols and splatter in dentistry: a brief review of the literature and infection control implications. The Journal of the American Dental Association. 2004;135(4):42937. PMID: 15127864 . Available from: 10.14219/jada.archive. 2004.0207.

7. Edwards DA, Man JC, Brand P, Katstra JP, Sommerer K, Stone HA. Inhaling to mitigate exhaled bioaerosols. Proceedings of the National Academy of Sciences of the United States of America. 2004;101(50):17383-8. PMID: 15583121. Available from: 10.1073/pnas.0408159101.

8. Coulthard P. Dentistry and coronavirus (COVID-19) - moral decision-making. British Dental Journal. 2020;228(7):503-5. PMID: 32277203. Available from: 10.1038/s41415-020-1482-1.

9. Balasubramanian S, Vinayachandran D. Bioaerosols from mouth-breathing: Under-recognized transmissible mode in COVID-19? Can Commun Dis Rep. 2021;47(56):276-278. PMID: 34220352. Available from: 10.14745/ccdr.v47i56a05.

10. Anfinrud P, Stadnytskyi V, Bax CE, Bax A. Visualizing SpeechGenerated Oral Fluid Droplets with Laser Light Scattering. N Engl J Med. 2020;2020:1-2. PMID: 32294341. Available from: 10.1056/NEJMc2007800.

11. Centers for Disease Control and Prevention (CDC). Strategies to Optimize PPE and 128 Equipment. 2020. Available at http s://www.cdc.gov/coronavirus/2019-ncov/hcp/ppe-129 strategy/index.html (accessed April 2020). . 
12. World Health Organization (WHO). Advice on the use of masks in the community, 131 during home care and in healthcare settings in the context of the novel coronavirus (COVID-19) outbreak. 2020. Available online at https://www. who.int/publications- detail/advice-on-the-use-of-masks-inthe-community-during-home-care-and-in 134 healthcaresettings-in-the-context-of-the-novel-coronavirus-(2019ncov)-outbreak (accessed April 2020). . 
Ready to submit your manuscript? Choose Biomedpress and benefit from:

- Fast, convenient online submission

- Through peer-review by experienced researchers

- Rapid publication on acceptance

- Free of charge (without publication fees)

Learn more http://www.biomedpress.org/journals/
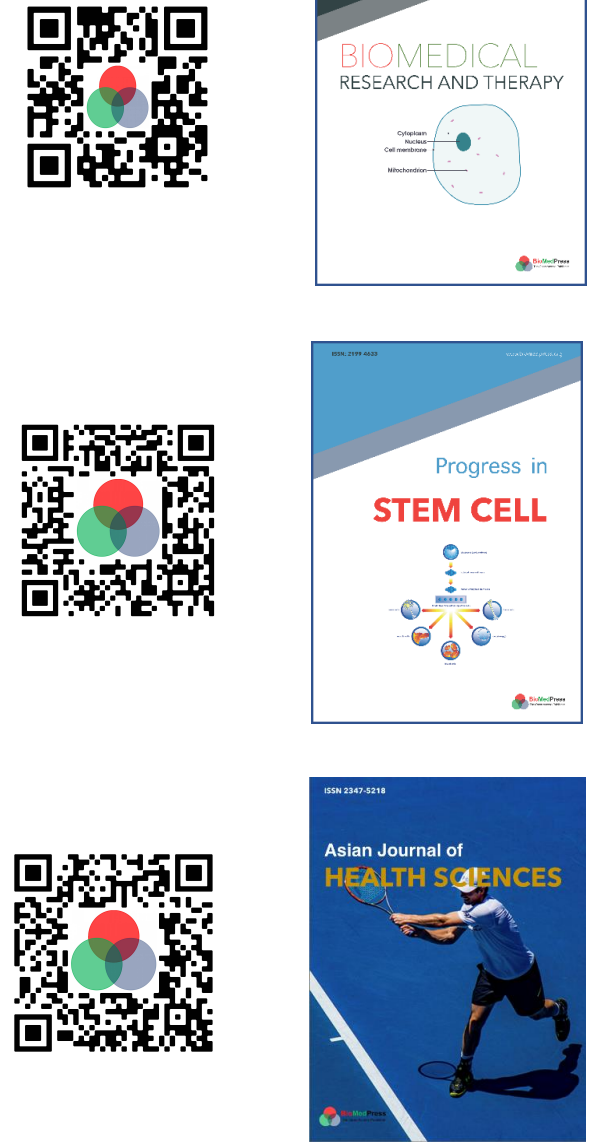

Asian Journal of Health Sciences

ISSN: 2347-5218

Indexed: Google Scholar

Acceptance Rate (2020): 72.89\%

Article Publishing Charge: Free

Submission to first editorial decision: 16.5 days

Biotechnological Research

ISSN: 2395-6763

Indexed: Google Scholar

Acceptance Rate (2020): $67.02 \%$

Article Publishing Charge: Free

Submission to first editorial decision: 28.5 days 